\title{
UJI DAYA HAMBAT EKSTRAK METANOL Selaginella delicatula DAN Diplazium dilatatum TERHADAP BAKTERI Staphylococcus aureus DAN Escherichia coli
}

\author{
Stery B. Oroh ${ }^{1)}$, Febby E.F. Kandou ${ }^{1)}$, Johanis Pelealu ${ }^{1)}$, Dingse Pandiangan ${ }^{1)}$ \\ 1) PS Biologi FMIPA Universitas Sam Ratulangi Manado \\ e-mail : stery_oroh@yahoo.com; febbyefkandou@yahoo.com; johanispelealu564@yahoo.com \\ dingsepan@yahoo.com
}

\begin{abstract}
ABSTRAK
Penelitian ini bertujuan untuk menguji daya hambat ekstrak metanol Selaginella delicatula dan Diplazium dilatatum terhadap pertumbuhan bakteri Staphylococcus aureus dan Escherichia coli. Pengujian daya hambat ekstrak terhadap bakteri menggunakan metode Kirby-Bauer, yaitu metode difusi dengan cakram kertas. Ekstrak $S$. delicatula menghambat pertumbuhan $S$. aureus pada konsentrasi ekstrak 30\%, 60\% dan 90\% dengan diameter zona hambat berturut-turut $0.00 \mathrm{~mm}, 6.70$ $\mathrm{mm}$ dan $7.80 \mathrm{~mm}$; serta menghambat pertumbuhan $E$. coli dengan diameter zona hambat berturutturut $0.00 \mathrm{~mm}, 8.40 \mathrm{~mm}$ dan $13.00 \mathrm{~mm}$. Ekstrak $D$. dilatatum menghambat pertumbuhan $S$. aureus pada konsentrasi ekstrak 30\%, 60\% dan 90\% dengan diameter zona hambat berturut-turut $0.00 \mathrm{~mm}$, $0.00 \mathrm{~mm}$ dan $6.70 \mathrm{~mm}$; serta menghambat pertumbuhan E. coli dengan diameter zona hambat berturut-turut $0.00 \mathrm{~mm}, 0.00 \mathrm{~mm}$ dan $8.00 \mathrm{~mm}$. Berdasarkan hasil penelitian yang diperoleh, dapat disimpulkan bahwa ekstrak $S$. delicatula dan $D$. dilatatum tergolong dalam kategori kuat dan sedang serta memiliki potensi sebagai bahan dasar antibakteri, karena kedua ekstrak menunjukkan daya hambatnya.
\end{abstract}

Kata kunci : tumbuhan paku, Selaginella delicatula, Diplazium dilatatum, Antibakteri, Staphylococcus aureus, Escherichia coli

\section{INHIBITION TEST OF METHANOL EXTRACT OF Selaginella delicatula AND Diplazium dilatatum AGAINST BACTERIA Staphylococcus aureus AND Escherichiacoli}

\begin{abstract}
This study aimed to test the inhibition of methanol extract of Selaginella delicatula and Diplazium dilatatum on the growth of Staphylococcus aureus and Escherichia coli. Testing inhibition of the extracts to bacterial using the Kirby-Bauer method, is the paper disk diffusion method. S. delicatula extract inhibited the growth of S. aureus at concentrations of extract $30 \%, 60 \%$ and $90 \%$ inhibition zone diameter respectively $0.00 \mathrm{~mm}, 6.70 \mathrm{~mm}$ and $7.80 \mathrm{~mm}$; and inhibit the growth of $E$. coli with inhibition zone diameter respectively $0.00 \mathrm{~mm}, 8.40 \mathrm{~mm}$ and $13.00 \mathrm{~mm}$. D. dilatatum extract inhibited the growth of $S$. aureus at concentrations of extract 30\%, 60\% and $90 \%$ inhibition zone diameter respectively $0.00 \mathrm{~mm}, 0.00 \mathrm{~mm}$ and $6.70 \mathrm{~mm}$; and inhibit the growth of E. coli with inhibition zone diameter respectively $0.00 \mathrm{~mm}, 0.00 \mathrm{~mm}$ and $8.00 \mathrm{~mm}$. Based on the results obtained, it can be concluded that the extract of $S$. delicatula and D. dilatatum classified in the category of medium and strong and has potential as a base material for both extracts showed antibacterial inhibitory power.
\end{abstract}

Keywords: ferns, Selaginella delicatula, Diplazium dilatatum, Antibacterial, Staphylococcus aureus, Escherichia coli.

\section{PENDAHULUAN}

Tumbuhan yang berpotensi sebagai antibakteri umumnya memiliki metabolit sekunder seperti senyawa golongan flavonoid, yaitu jenis flavon, flavonol dan flavanonon (Bylka et al., 2004), tanin, alkaloid dan saponin (Abdillah, 2006). Flavonoid adalah kelompok fenol yang mempunyai 
kecenderungan untuk menghambat aktivitas enzim mikroba (Nikham dan Basjir, 2012) dan tanin dapat menggumpalkan protein (Abdillah, 2006). Tumbuhan paku yang telah diketahui kandungan metabolit sekundernya dan diantaranya merupakan metabolit sekunder yang berpotensi sebagai antibakteri adalah Selaginella delicatula dan Diplazium dilatatum.

Arini dan Kinho (2012) melaporkan bahwa genus Diplazium dan Selaginella telah dimanfaatkan oleh masyarakat sebagai tumbuhan obat. Diplazium accendens digunakan sebagai obat pasca persalinan dan Selaginella sp. sebagai obat pasca persalinan, obat penambah darah dan obat nyeri pada ulu hati. Selaginella dan Diplazium merupakan tumbuhan terestrial yang biasanya tumbuh di tebing di daerah pegunungan (1100-1300 dpl). Genus Selaginella pada umumnya memiliki senyawa steroid, triterpen, tanin dan katekin (Irudayaraj et al., 2010). Jenis Selaginella plana, S. willdenovii dan S. mayeri memiliki senyawa tanin, saponin dan flavonoid (Sopyati, 2009). Genus Diplazium memiliki senyawa flavonoid, saponin, tanin dan steroid (Osabor et al., 2010).

Pemanfaatan Selaginella delicatula dan Diplazium dilatatum yang tumbuh di Indonesia sebagai antibakteri belum dilaporkan. Oleh karena itu, perlu dilakukan pengujian daya hambat $S$. delicatula dan $D$. dilatatum yang tumbuh di Indonesia khususnya di daerah Sulawesi Utara terhadap pertumbuhan bakteri penyebab penyakit. Bakteri penyebab penyakit diantaranya adalah Staphylococcus aureus dan Escherichia coli. Penyakit yang disebabkan oleh $S$. aureus dan E. coli, yaitu abses, gingivitis, infeksi saluran pencernaan, infeksi kulit, sinusitis, diare, sepsis dan meningitis. Penyakit tersebut merupakan penyakit yang sering dialami kebanyakan masyarakat, sehingga perlu dilakukan pengujian untuk menghambat atau membunuh bakteri tersebut. Hal ini dilakukan sebagai usaha pengembangan tumbuhan yang berkhasiat obat dan usaha menemukan sumber antibakteri baru yang berasal dari alam. Penemuan sumber antibakteri baru yang berasal dari bahan alam dapat membantu mengatasi masalah resistensi bakteri khususnya bakteri patogen.

\section{METODE PENELITIAN Tempat dan Waktu Penelitian}

Penelitian dilaksanakan di Laboratorium Mikrobiologi dan Ekologi FMIPA UNSRAT Manado dan pengambilan sampel di Desa Ampreng Kecamatan Langowan Barat. Penelitian dilaksanakan bulan September-Oktober 2014.

\section{Alat dan Bahan}

Alat-alat yang digunakan, yaitu timbangan digital, alat gelas, hot plate, laminar air flow autoklaf, jarum inokulasi lurus, lampu Bunsen, mortar dan pestle, lemari pendingin, inkubator, evaporator, blender, kertas saring, pinset, cakram kertas dengan diameter $5 \mathrm{~mm}$, jangka sorong dan kamera.

Bahan-bahan yang digunakan, yaitu daun Selaginella delicatula dan Diplazium dilatatum, biakan murni bakteri Staphylococcus aureus dan Escherichia coli, medium Nutrient Agar (NA), medium Nutrient Broth (NB), akuades, metanol, zat antibiotik (Ampicillin) dan lisol (antiseptik).

\section{Penyiapan Sampel dan Pembuatan Ekstrak}

Tumbuhan paku Selaginella delicatula dan Diplazium dilatatum diambil di Desa Ampreng Kecamatan Langowan Barat dan diidentifikasi menggunakan buku dari Piggott \& Piggott (1988) dan buku de Winter \& Amoroso (2003) serta dari artikel ilmiah. Selanjutnya, daun tumbuhan paku dibersihkan, dikeringanginkan sampai beratnya konstan, ditimbang sebanyak 50 gram, kemudian dipotong kecil dan dihaluskan. Sampel tumbuhan paku yang telah halus direndam dengan metanol selama $3 \times 24$ jam, setelah itu ekstrak disaring sehingga diperoleh filtrat. Filtrat yang diperoleh dievaporasi dengan evaporator sampai diperoleh ekstrak pekat. Ekstrak pekat diuapkan kembali dengan meletakkannya di wadah terbuka sehinggga diperoleh ekstrak kering. Ekstrak kering yang diperoleh dilarutkan dengan akuades sampai konsentrasinya menjadi 30\%, 60\% dan 90\%. Larutan antibiotik, yaitu Ampicillin dibuat dengan cara $10 \mathrm{mg}$ Ampicillin dilarutkan dalam $10 \mathrm{ml}$ akuades. 


\section{Pembuatan Medium Tumbuh Bakteri dan Pembiakan Bakteri}

Medium Nutrient Broth (NB) 1,3 g dilarutkan dalam $100 \mathrm{ml}$ akuades dan medium Nutrient Agar (NA) 6 g dilarutkan dalam 300 $\mathrm{ml}$ akuades, kemudian dipanaskan hingga larut. Medium NB yang telah larut dimasukkan ke tabung reaksi masing-masing sebanyak $5 \mathrm{ml}$ dan Medium NA dimasukkan ke tabung reaksi dan cawan petri masingmasing sebanyak $5 \mathrm{ml}$ dan $15 \mathrm{ml}$, kemudian disterilisasi dengan autoklaf pada suhu $120^{\circ} \mathrm{C}$ selama 15 menit. Tabung reaksi berisi medium NA sebanyak $5 \mathrm{ml}$ dibiarkan mengeras pada posisi kemiringan $15^{0}$ setelah sterilisasi medium NB dan NA selesai. Biakan murni Staphylococcus aureus dan Escherichia coli diinokulasi secara aseptik dalam tabung reaksi berisi medium miring NA steril masingmasing tiga buah tabung reaksi, kemudian diinkubasikan pada suhu $37^{\circ} \mathrm{C}$ selama 24 jam, setelah itu diinokulasi kembali dari medium NA ke medium NB dan diinkubasikan pada suhu $37^{\circ} \mathrm{C}$ selama 24 jam.

\section{Uji Daya Hambat Ekstrak terhadap Bakteri}

Metode pengujian yang digunakan adalah metode Kirby-Bauer, yaitu metode difusi dengan cakram kertas. Biakan bakteri Staphylococcus aureus dan Escherichia coli dituangkan secara aseptik sebanyak $3 \mathrm{ml}$ dari medium NB ke cawan petri steril yang berisi medium NA yang masih cair, kemudian cawan petri diaduk. Cakram kertas dimasukkan dalam ekstrak tumbuhan paku dengan konsentrasi berbeda-beda, yaitu 30\%, 60\% dan $90 \%$ dan juga dalam kontrol positif (Ampicillin) dan kontrol negatif (aquades) selama \pm 1 menit. Cakram kertas yang sudah direndam dalam ekstrak diletakkan secara aseptik di atas permukaan medium NA yang telah diinokulasi $S$. aureus dan $E$. coli dengan pinset steril, kemudian diinkubasikan pada suhu $37^{\circ} \mathrm{C}$ selama $1 \times 24$ jam. Setelah inkubasi selesai, zona bening di sekitar cakram kertas diamati dan diukur diameternya. Pengujian daya hambat ekstrak tumbuhan paku terhadap bakteri $S$. aureus dan E. coli dilakukan tiga kali ulangan untuk setiap konsentrasi yang diuji.

\section{Analisis Data}

Diameter zona daya hambat ekstrak tumbuhan paku disajikan dalam tabel dan gambar. Efektivitas antibakteri konsentrasi ekstrak tumbuhan paku terhadap antibiotik dihitung berdasarkan persamaan (Tangapo, 2005), yaitu:

$$
\mathrm{E}=(\mathrm{D} / \mathrm{Da}) \times 100 \%
$$

Keterangan:

E: efektivitas antibakteri (\%)

D: diameter zona hambat ekstrak tumbuhan paku $(\mathrm{mm})$

Da: diameter zona hambat antibiotik ( $\mathrm{mm})$

\section{HASIL DAN PEMBAHASAN Daya Hambat Ekstrak}

Daya hambat ekstrak yang diuji ditunjukkan dengan adanya zona bening di sekitar cakram kertas. Zona bening di sekitar cakram kertas merupakan daerah difusi ekstrak yang mempengaruhi pertumbuhan bakteri. Besar diameter dari zona hambat yang terbentuk dapat menunjukkan kekuatan antibakteri dari ekstrak yang digunakan. Penggolongan kekuatan antibakteri Davis dan Stout (1971) mempermudah dalam menggolongkan kemampuan dari diameter yang diperoleh. Ekstrak dengan diameter hambatan lebih dari $20 \mathrm{~mm}$ termasuk dalam kategori sangat kuat, diameter hambatan berkisar dari 10-20 $\mathrm{mm}$ termasuk dalam kategori kuat, diameter hambatan berkisar dari 5-10 mm termasuk dalam kategori sedang dan diameter hambatan kurang dari $5 \mathrm{~mm}$ termasuk dalam kategori lemah.

\section{Ekstrak Selaginella delicatula}

Hasil pengujian daya hambat ekstrak Selaginella delicatula pada konsentrasi $60 \%$ dan $90 \%$ terbentuk zona bening di sekitar cakram kertas pada bakteri $S$. aureus dan $E$. coli (Gambar 2 dan 3), sedangkan pada konsentrasi $30 \%$ tidak terbentuk zona bening (Gambar 1). 
Tabel 1. Rataan diameter zona hambat ekstrak Selaginella delicatula terhadap bakteri Staphylococcus aureus dan Escherichia coli

\begin{tabular}{ccr}
\hline \multirow{2}{*}{$\begin{array}{c}\text { Konsentrasi } \\
(\%)\end{array}$} & \multicolumn{2}{c}{$\begin{array}{c}\text { Rataan Diameter Zona Hambat } \\
\text { Ekstrak S. delicatula }(\mathrm{mm})\end{array}$} \\
\cline { 2 - 3 } & S. aureus & \multicolumn{1}{c}{ E. coli } \\
\hline 30 & $0.00 \pm 0.00$ & $0.00 \pm 0.00$ \\
60 & $6.70 \pm 0.31$ & $8.40 \pm 0.40$ \\
90 & $7.80 \pm 0.06$ & $13.00 \pm 3.50$
\end{tabular}

Hal ini menunjukkan bahwa ekstrak $S$. delicatula pada konsentrasi rendah belum mampu mengganggu metabolisme bakteri uji sehingga masih terdapat pertumbuhan bakteri di sekitar cakram kertas. Diameter zona hambat ekstrak $S$. delicatula semakin meningkat bersamaan dengan meningkatnya konsentrasi ekstrak (Tabel 1). Hal ini disebabkan oleh kadar senyawa aktif yang menghambat atau membunuh bakteri meningkat seiring dengan meningkatnya konsentrasi ekstrak. Daya hambat ekstrak Selaginella delicatula terhadap bakteri Staphylococcus aureus pada konsentrasi 60\% dan $90 \%$ memiliki kekuatan antibakteri yang termasuk kategori sedang. Hasil berbeda diperoleh dari daya hambat yang dihasilkan oleh ekstrak $S$. delicatula terhadap bakteri Escherichia coli pada konsentrasi $60 \%$ dan $90 \%$. Ekstrak S. delicatula pada konsentrasi $60 \%$ termasuk kategori sedang dalam menghambat bakteri E. coli, sedangkan pada konsentrasi $90 \%$ termasuk kategori kuat. Hal ini menandakan bahwa ekstrak ini sudah memiliki aktivitas sebagai antibakteri mulai dari konsentrasi sedang sampai tinggi. Menurut Irudayaraj et al. (2010), Selaginella mengandung flavonoid yang merupakan salah satu metabolit sekunder yang berpotensi sebagai antibakteri. Hal ini yang menjadi faktor adanya aktivitas antibakteri dari ekstrak S. delicatula.

Zona hambat yang dihasilkan ekstrak ini lebih besar pada bakteri E. coli dibandingkan $S$. aureus (Tabel 1). Menurut Davidson et al. (2005), senyawa antibakteri yang berupa asam-asam organik memiliki daya hambat yang lebih besar terhadap bakteri Gram negatif. Genus Selaginella memiliki asam organik (Gui et al., 2009).

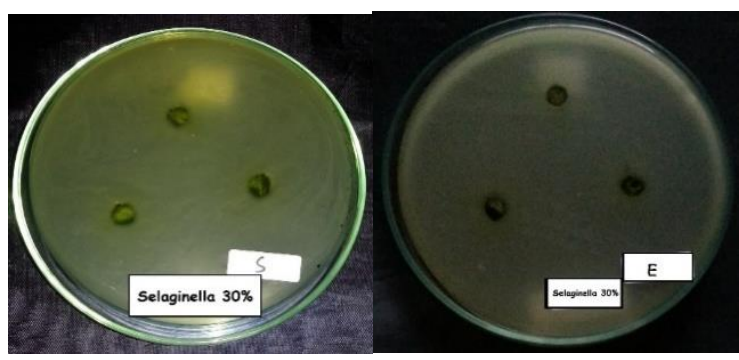

(a)

(b)

Gambar 1. Zona hambat ekstrak S. delicatula terhadap (a) Staphylococcus aureus dan (b) Escherichia coli pada konsentrasi 30\%

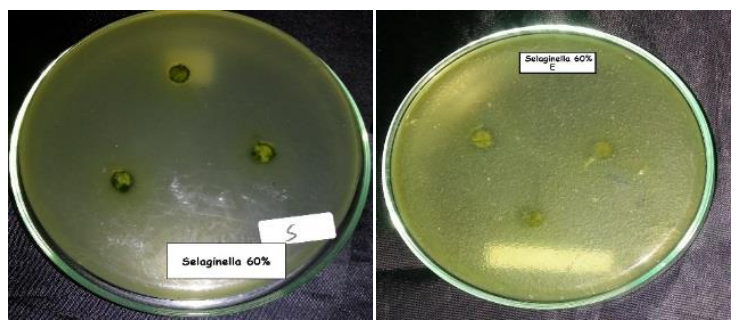

(a)

(b)

Gambar 2. Zona hambat ekstrak S. delicatula terhadap (a) Staphylococcus aureus dan (b) Escherichia coli pada onsentrasi $60 \%$

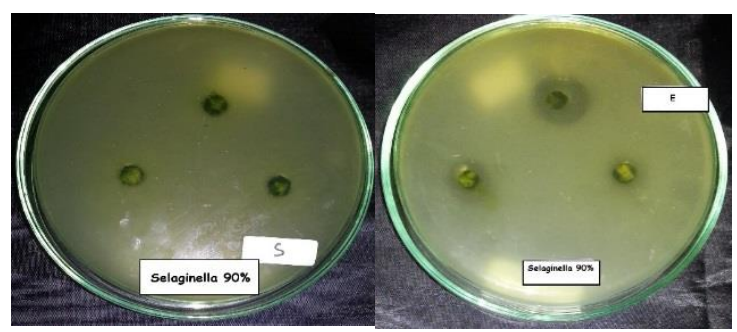

(a)

(b)

Gambar 3. Zona hambat ekstrak S. delicatula terhadap (a) Staphylococcus aureus dan (b) Escherichia coli pada konsentrasi 90\%

\section{Ekstrak Diplazium dilatatum}

Ekstrak Diplazium dilatatum hanya menunjukkan daya hambatnya terhadap bakteri $S$. aureus dan E. coli pada konsentrasi $90 \%$, namun ekstrak ini memiliki daya hambat lebih besar terhadap E. coli dibandingkan $S$. aureus. Ekstrak D. dilatatum konsentrasi 90\% menghasilkan diameter zona penghambatannya sebesar $6.70 \mathrm{~mm}$ terhadap bakteri $S$. aureus dan $8.00 \mathrm{~mm}$ terhadap bakteri E. coli (Tabel 2). 
Tabel 2. Rataan diameter zona hambat ekstrak Diplazium dilatatum terhadap bakteri Staphylococcus aureus dan Escherichia coli

\begin{tabular}{ccc}
\hline \multirow{2}{*}{$\begin{array}{c}\text { Konsentrasi } \\
(\%)\end{array}$} & \multicolumn{2}{c}{$\begin{array}{c}\text { Rataan Diameter Zona } \\
\text { Hambat Ekstrak } D . \\
\text { dilatatum }(\mathrm{mm})\end{array}$} \\
\cline { 2 - 3 } & $\begin{array}{cc}\text { S. aureus } \\
\text { E. coli }\end{array}$ \\
\hline 30 & $0.00 \pm 0.00$ & $0.00 \pm 0.00$ \\
60 & $0.00 \pm 0.00$ & $0.00 \pm 0.00$ \\
90 & $6.70 \pm 0.35$ & $8.00 \pm 0.40$
\end{tabular}

Ekstrak $D$. dilatatum pada konsentrasi $30 \%$ dan $60 \%$ tidak menunjukkan diameter zona hambatnya terhadap bakteri uji (Gambar 4 dan 5). Hal ini menandakan bahwa pada konsentrasi rendah dan sedang ekstrak $D$. dilatatum belum mampu mengganggu metabolisme bakteri dan merusak dinding sel bakteri $S$. aureus dan E. coli. Ekstrak yang menunjukkan daya hambatnya disebabkan oleh banyak sampel yang digunakan setiap konsentrasi.

Daya hambat ekstrak D. dilatatum terhadap bakteri $S$. aureus dan E. coli hanya terdapat pada konsentrasi 90\% (Gambar 6). Ekstrak D. dilatatum konsentrasi $90 \%$ memiliki kekuatan antibakteri yang termasuk kategori sedang karena memiliki diameter zona hambat berkisar 5-10 mm. Hal ini menandakan bahwa pada konsentrasi tinggi, yaitu konsentrasi 90\% ekstrak ini sudah memiliki mekanisme kerja sebagai antibakteri dan sudah mampu mengganggu metabolisme bakteri. Menurut Osabor et al. (2010), Diplazium mengandung flavonoid yang merupakan salah satu metabolit sekunder yang berpotensi sebagai antibakteri. Hal ini yang menjadi faktor adanya aktivitas antibakteri dari ekstrak $D$. dilatatum. Zona hambat yang dihasilkan ekstrak ini lebih besar pada bakteri E. coli dibandingkan $S$. aureus. Pada umumnya, bakteri Gram positif lebih mudah dihambat atau dibunuh dibandingkan bakteri Gram negatif. Hal ini menandakan bahwa senyawa aktif ekstrak ini lebih aktif dalam menghambat bakteri Gram negatif.

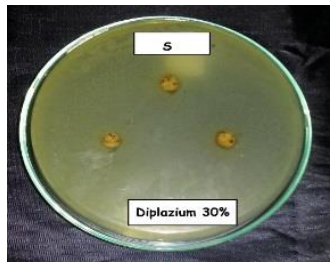

(a)

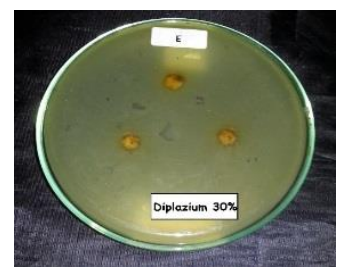

(b)
Gambar 4. Zona hambat ekstrak D. ilatatum terhadap (a) Staphylococcus aureus dan (b) Escherichia coli pada konsentrasi $30 \%$

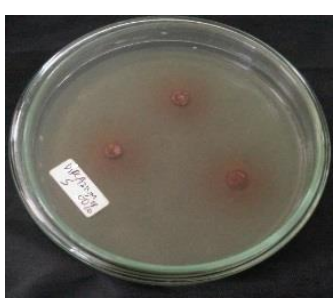

(a)

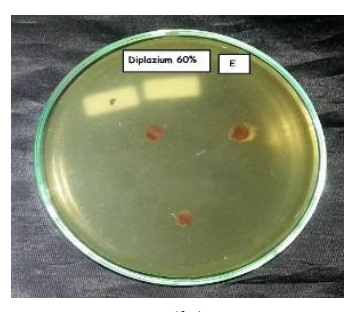

(b)
Gambar 5. Zona hambat ekstrak D. dilatatum terhadap (a) Staphylococcus aureus dan (b) Escherichia coli pada konsentrasi $60 \%$

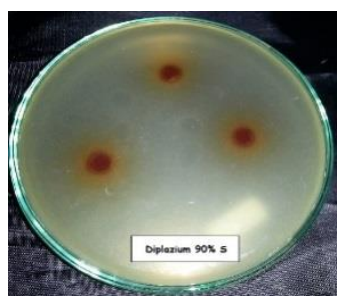

(a)

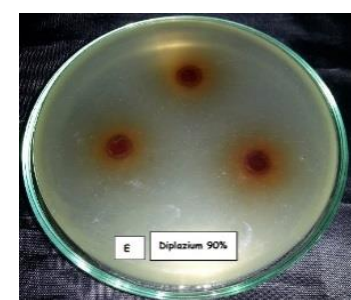

(b)
Gambar 6. Zona hambat ekstrak D. dilatatum terhadap (a) Staphylococcus aureus dan (b) Escherichia coli pada konsentrasi $90 \%$

\section{Efektivitas Antibakteri}

Efektivitas ekstrak diperoleh dengan membandingkan daya hambatnya dengan daya hambat dari kontrol positif, yaitu larutan antibiotik (Ampicillin). Efektivitas antibakteri ekstrak Selaginella delicatula dan Diplazium dilatatum secara keseluruhan masih tergolong kurang efektif. Hal ini terlihat dari persentase yang kurang dari 50\% diperoleh dari hasil perhitungan dengan persamaan $\mathrm{E}=(\mathrm{D} / \mathrm{Da}) \mathrm{x}$ $100 \%$ (Tabel 3). 
Tabel 3. Efektivitas antibakteri ekstrak Selaginella delicatula dan Diplazium dilatatum

\begin{tabular}{lccc}
\hline \multirow{2}{*}{ Cakram } & Konsentr & \multicolumn{2}{c}{ Efektivitas $(\%)$} \\
\cline { 3 - 4 } & asi $(\%)$ & S. aureus & E. coli \\
\hline Selaginella & 30 & 0.00 & 0.00 \\
delicatula & 60 & 19.25 & 17.14 \\
& 90 & 22.41 & 26.53 \\
Diplazium & 30 & 0.00 & 0.00 \\
dilatatum & 60 & 0.00 & 0.00 \\
& 90 & 19.25 & 16.33 \\
\hline
\end{tabular}

Berdasarkan Tabel 3, terlihat bahwa ekstrak Selaginella delicatula 90\% menunjukkan efektivitas antibakteri tertinggi terhadap Staphylococcus aureus dan Escherichia coli, yaitu $22.41 \%$ dan $26.53 \%$. Hal ini disebabkan karena pada konsentrasi tersebut jumlah ekstrak yang digunakan lebih banyak dibandingkan dengan perlakuan lainnya dan senyawa aktif yang terdapat pada $S$. delicatula lebih banyak dibandingkan $D$. dilatatum. Ekstrak yang tidak memiliki efektivitas terhadap bakteri $S$. aureus dan E. coli adalah $S$. delicatula $30 \%$ dan D. dilatatum $30 \%, 60 \%$. Hal ini terlihat dari nilai efektivitas yang paling kecil dibandingkan perlakuan lainnya. Efektivitas yang rendah disebabkan oleh karena pada konsentrasi tersebut jumlah ekstrak yang digunakan sedikit dan senyawa aktif yang terdapat pada jenis tumbuhan paku tersebut juga sedikit.

Efektivitas yang masih rendah menandakan bahwa kadar senyawa aktif sebagai antibakteri pada tumbuhan paku yang digunakan masih rendah. Hal ini disebabkan karena pada penelitian ini masih menggunakan ekstrak kasar. Penggunaan ekstrak dengan senyawa tunggal yang telah diketahui sebagai antibakteri, misalnya Ampicilin akan lebih efektif dalam menghambat pertumbuhan bakteri. Hal ini sesuai dengan hasil yang diperoleh, yaitu Ampicillin sebagai kontrol positif memiliki zona hambat yang lebih besar dibandingkan ekstrak lima jenis tumbuhan paku, yaitu 34.80 mm terhadap S. aureus dan 49.00 terhadap E. coli.

\section{KESIMPULAN}

Berdasarkan hasil penelitian dapat disimpulkan bahwa ekstrak Selaginella delicatula pada konsentrasi $90 \%$ memiliki daya hambat yang tergolong kuat dalam menghambat pertumbuhan bakteri Escherichia coli. Ekstrak Diplazium dilatatum pada konsentrasi $90 \%$ memiliki daya hambat yang tergolong sedang dalam menghambat pertumbuhan bakteri $S$. aureus dan E. coli.

\section{SARAN}

Perlu dilakukan penelitian lebih lanjut dengan hanya menggunakan senyawa tunggal yang bermanfaat sebagai antibakteri pada tumbuhan paku Selaginella delicatula dan Diplazium dilatatum. Selain itu, perlu dilakukan pengujian daya hambat menggunakan metode dilusi dan pelarut serta jenis bakteri yang berbeda.

\section{DAFTAR PUSTAKA}

Abdillah A. 2006. Aktivitas Antiproliferasi Ekstrak Air Daun Sisik Naga (Pyrrosia nummularifolia (Sw.) Ching) terhadap Sel Lestari Tumor HeLa secara In Vitro [Skripsi]. Bogor. Institut Pertanian Bogor.

Arini D.I.D. dan Kinho J. 2012. Keragaman Jenis Tumbuhan Paku (Pteridophyta) Di Cagar Alam Gunung Ambang Sulawesi Utara. Balai Penelitian Kehutanan Manado. 2 (1). 17-39.

Bylka W., M. Szaufer-Hajdrych, I. Matlawska, O. Goslinska. 2004. Antimicrobial Activity of Isocytisoside and Extracts of Aquilegia vulgaris L. Letters in Applied Microbiology. 39. 9397.

Davidson P.M., J.N. Sofos, A.I. Branen. 2005. Antimicrobial in Food third edition. New York. Taylor and Francis Group.

Davis W.W. dan Stout T.R. 1971. Disc Plate Method of Microbiological Antibiotic Assay. Applied Microbiology. 659-665.

de Winter W.P. dan Amoroso V.B. 2003. Plant Resources of South-East Asia no.15(2) Cryptogams : Ferns and Fern Allies. Bogor. PROSEA Foundation Bogor.

Gracelin D.H.S., Britto A.J.D., Kumar P.B.J.R. 2012. Antibacterial Screening of A Few Medicinal Ferns against Antibiotic Resistant Phyto Pathogen. International Journal of 
Pharmaceutical Sciences and Research. 3 (3). 868-873.

Gui S.T., Kang P.X., Fu S.L., Chen J.W., Tuo Y.L., Chang P.H., Jian S., Ying J.Z., Yuan J.L. 2009. Selaginellin C, a new natural pigment from Selaginella pulvinata Maxim (Hook et Grev.). Journal of Asian Natural Products Research. 11 (12). 1001-1004.

Irudayaraj V., Janaky M., M. Johnson, N. Selvan. 2010. Preliminary Phytochemical and Antimicrobial Studies On A Spike-Moss Selaginella inaequalifolia (Hook. \& Grev.) Spring. Asian Pacific Journal Of Tropical Medicine. 957-960.

Khoiri M. 2009. Aktivitas Anti Tumor Ekstrak Etanol Selaginella Pada Sel Tumor Kelenjar Mamari Mencit (Mus musculus) $\mathrm{C} 3 \mathrm{H}$ [Tesis]. Bogor. Institut Pertanian Bogor.

Nikham dan Basjir T.E. 2012. Uji Bahan Baku Antibakteri dari Buah Mahkota Dewa (Phaleria macrocarpa) Hasil Iradiasi Gamma dan Antibiotik Terhadap Bakteri Patogen. Prosiding Pertemuan Ilmiah Ilmu Pengetahuan dan Teknologi Bahan. ISSN 1411-2213. 168-174.
Osabor V.N., G.E. Egbung, U.M. Ntuk. 2010. Chemical Evaluation of The Leaves of Diplazium summattii (Nyama Idim). Research Journal Of Agriculture And Biological Sciences. 6(6): 1074-1077.

Piggott, A.G. dan Piggott, C.J. 1988. Fern of Malaysia in Colour. Kuala Lumpur. Tropical Press SDN. BHD. Malaysia.

Sopyati P.D. 2009. Pertumbuhan dan Kandungan Bahan Bioaktif dari Selaginella plana, S. willdenovii dan $S$. mayeri Pada Beberapa Tingkat Naungan [Skripsi]. Bogor. Institut Pertanian Bogor.

Tangapo A.M. 2005. Efektivitas Antibakteri Ekstrak Tumbuhan Daun Sendok (Plantago major) Terhadap Staphylococcus aureus dan Pseudomonas aeruginosa [Skripsi]. Manado. Universitas Sam Ratulangi.

Tongco J.V.V., Ronald A.P.V., Remil M. A., Ramon A.R. 2014. Nutritional and Phytochemical Screening and Total Phenolic and Flavonoid Content Of Diplazium esculentum (Retz.) Sw. from Philippines. Journal of Chemical and Pharmaceutical Research. 6 (8). 238242. 